\title{
Use of Bound Morphem form in Novel Title 5 CM by Donny Dhirgantoro
}

\author{
Aziz Thaba ${ }^{1}$, Amrul $^{1}$, Cici Mahmut ${ }^{2}$, Abdul Karim Mahmut ${ }^{3}$, Nurfitri Wahidah ${ }^{4}$, \\ Arianto Gunawan ${ }^{4}$, Khazwar Pratama ${ }^{4}$, Sri Devi Sahura ${ }^{4}$, Darna ${ }^{4}$, Hajarulhuda Dewi Anjani ${ }^{4, ~ *, ~}$ \\ Ayu Mutmainna ${ }^{4}$, Wardah Afdaliah ${ }^{4}$, Aulia Magfirah ${ }^{4}$, Siti Sholeha $^{4}$ \\ ${ }^{1}$ Matutu: Non-governmental Education Research and Development, Makassar, South Sulawesi, Indonesia \\ ${ }^{2}$ Department of Development Economics \& Planning, Faculty of Economics \& Business, Postgraduate of Hasanuddin University, Makassar, \\ South Sulawesi, Indonesia \\ ${ }^{3}$ Departement of Education Technology, Faculty of Education and Teacher Training, University of Muhammadiyah Makassar, Makassar, South \\ Sulawesi, Indonesia \\ ${ }^{4}$ Departement of Indonesian Language and Literature Education, Faculty of Education and Teacher Training, University of Muhammadiyah \\ Makassar, South Sulawesi, Indonesia
}

Email address:

hajarulhudada15@gmail.com (H. D. Anjani)

${ }^{*}$ Corresponding author

\section{To cite this article:}

Aziz Thaba, Amrul, Cici Mahmut, Abdul Karim Mahmut, Nurfitri Wahidah, Arianto Gunawan, Khazwar Pratama, Sri Devi Sahura, Darna, Hajarulhuda Dewi Anjani, Ayu Mutmainna, Wardah Afdaliah, Aulia Magfirah, Siti Sholeha. Use of Bound Morphem form in Novel Title 5 CM by Donny Dhirgantoro. International Journal of Literature and Arts. Vol. 8, No. 5, 2020, pp. 287-291. doi: 10.11648/j.ijla.20200805.14

Received: July 13, 2020; Accepted: July 25, 2020; Published: September 3, 2020

\begin{abstract}
Language is the main vehicle in literature. The phenomenon of using language in literature has its own appeal to be investigated. One of the phenomena of using language in literary works is the use of morphemes. Morpheme is the smallest language unit that has a meaning or meaning as well as a reference for the formation of other language units. This study aims to describe the bound morpheme in a novel entitled $5 \mathrm{~cm}$ by Donny Dhirgantoro. This is a descriptive qualitative research. The purpose of this study was to determine the use of morphemes bound in literary texts in the form of a novel titled $5 \mathrm{~cm}$ by Donny Dhirgantoro. Unit of analysis in the form of bound morphemes used in the data source (novel $5 \mathrm{~cm}$ by Donny Dhirgantoro). Researchers are key instruments, data collection is done by reading the novel entitled $5 \mathrm{~cm}$ by Donny Dhigantoro, identifying bound morphemes, grouping bound morphemes, analyzing bound morphemes and drawing conclusions. The results showed that the use of bound morphemes contained in Donny Dhirgantoro's novel were bound morphemes in the form of affixes totaling 474 words, bound morphemes in the form of clitics or proclites totaling 531 words while bound morphemes were eleven words.
\end{abstract}

Keyword: Bound Morpheme, Novel, 5 CM

\section{Introduction}

Language is a communication tool for humans. In linguistics, several branches of science study languages, phonology which studies sound system, morphology that studies the intricacies of word formation, syntax in phrases, clauses and sentences, and lesicons in word grammar [1]. Branch of linguistics related to the form of words, namely morphology. The form of words can change one of them with the affix affixation process [2]. One form of affixes in Indonesian is the affix men-, words that affix men- are verbal word groups. Judging from the function of the affix me-n in Indonesian has similarities with the affix $\mathrm{N}$-.

If so, the forms of language are affixes such as me $(\mathrm{N})$-, berm, -an, -em-, or particles like -lah, -ah, -tah, what are they called? These forms cannot be called syllables because prefixes or particles already have meanings while syllables do not have meaning or meaning. Affixes and pertikel also cannot be called a word because the form above cannot stand alone because it must be attached to other forms [3].

Morphology is a part of linguistics that discusses the intricacies of word forms and changes in the form of word 
groups and meanings or morphology supported by the subtleties of word forms and word-change functions, both grammatical and semantic functions [4]. In an international dictionary, in Munirah [5] argues that, morphology comes from the Greek Morphe combined with logos Morphe means form and logos means science. The sound / o / contained in the morphe is the sound of pliers usually appear between two words combined. For example, when psyche is combined with logos, a sound /o/ like that appears between the two words combined to form the word psychology (psychology). Likewise, when phon is combined with logic, a sound /o/ phonology emerges until a word is formed.

Morphology is a branch of language in which learning about word forms, word changes and word meanings [6]. There are various fields of study of morphology, one of the studies is morphophonemic. Morphophonemic is a change in the phonemic shape of a morpheme caused by phonemes that are around it or by other syntactic conditions [7]. To find out the morphophonemic processes that occur, it is necessary to reveal as many morphophonemic events as possible. Bound morphemes are morphemes which must first be joined with other morphemes to be used in speech. For example (stopping), (fighting), and (winding) that requires others to have meaning [8].

From these events morphophonemic types can be grouped based on the similarity of the process. These conclusions can then be used as rules for correct word formation [9]. Do not cause mistakes to the level of meaning. If something goes wrong at the level of meaning, it will interfere with the ongoing communication. If there is a disruption in communication activities, then the main function of language is lost as a communication tool. To explain this, linguists created a morpheme concept. A word does not only consist of syllables that are not meaningful, but rather from one or more meaningful forms of language, morpheme [10].

Novel $5 \mathrm{~cm}$ written by Donny Dhirgantoro is a mega best seller novel that has printed hundreds of thousands of copies throughout Indonesia. The book produced by Donny Dirgantoro has elements of nationalism, love, dreams, friendship and struggle. Something that makes this book special and well received, especially by the younger generation, is how the writer incorporates all of these elements into a reading that is touching, inspiring, full of learning and more entertaining.

Novel $5 \mathrm{~cm}$ as popular literature. Popular literature is a literary work that tends to use everyday language among teenagers, this work is often called a pop work [11]. popular literature is literary forms that have roots in the needs, ways of thinking, knowledge, problems and tastes most people initially, most popular or popular pop culture is commercial (public), open and born of the people, and of course popular with the people.

\section{Method}

The type of this research is descriptive qualitative on bound morphemes contained in the $5 \mathrm{Cm}$ novel by Dhonny Dhirgantoro. This research is a descriptive qualitative research. Pradopo (2001), descriptive research is research aimed at describing the exact characteristics of an individual, symptoms that occur or are real. Moleong (1990), qualitative research as research that does not carry out calculations. Furthermore Moleong characterizes qualitative research as follows: natural setting, basic theory, description, more concerned with process than outcome, 'boundaries' determined by 'focus', specific criteria for data validity, temporary designs, and research results are negotiated and agreed together.

The data in this study is a $5 \mathrm{~cm}$ novel by Dhonny Dhirgantoro published in 2005 consisting of 379 pages, while the reference is the book Morphology and as a source of data that is morpheme bound in the novel, so that researchers easily find out how to know a morpheme.

In identifying morphemes in novels, the authors collect data using documentation and note-taking techniques. Moleong [14] which states that documentation has reasons that can be accounted for as: Documentation is a rich and stable source; Documentation that is in accordance with qualitative research, because it is natural in nature which is in accordance with the context; Documentation can be used as evidence for an examiner.

Based on the data collection techniques used, the data were analyzed using descriptive analysis. The data analysis can be done as follows: Exactly read a novel entitled $5 \mathrm{~cm}$ by Donny Dhigantoro; Identify bound morphemes; Group bound morphemes; Analyzing bound morphemes; Summing up the results of identification.

\section{Results and Discussion}

As stated above, the main object of study in this study is the Use of Bound Morphemes in a novel written in $5 \mathrm{~cm}$ by Donny Dhirgantoro published by P. taT. Grafindo, Jakarta in 2005.

After the author examines the use of bound morphemes in the $5 \mathrm{~cm}$ novel by Donny Dhirgantoro, the authors get a morpheme bound type affix (affix) consisting of prefixes, infixes, suffixes and confixes. Then the data can be described as follows.

1. Morphemes are bound by affixes consisting of prefixes, infixes, suffixes and confixes.

A. Prefixes, -ber contained in the novel amounted to 114 words, prefixes -ter 47 words, prefixes 33 words, prefixes in 4 words, prefixes -me 32 words, prefixes 24 words while prefixes -mem 42 words, so the overall number of words that contained in the novel is 296 words. For example, the word sounds is a combination between bound morpheme and free morpheme, bound morpheme is morpheme -ter, free morpheme that is listened.

B. Infix (insertions) are not found in the novel.

C. Suffixes (suffixes), suffixes found in the 4-word novel, suffixes -an 20 words, suffixes -woman, -man and wati are not contained in the novel, so the total number of words in the novel is 24 words.

D. D. The confix (prefix and suffix) of the confix, which is contained in the novel 93 words, confix per-role, 6 words, 
confix right, 2 words, confix right, 6 words, confix, right, 4 words, confix is right, 22 words, confix is right, 9 words, while confix is 12 words, so the whole word in the novel is 107 words.

So the total amount of affixation contained in the $5 \mathrm{~cm}$ novel by Donny Dhirgantoro is 474 words, but not all types of affixation are found in the novel, especially infix (suffix). The data below includes bound morphemes in the form of affixes, including: prefix (air, tar, meng, di), infix (el, em, er), supix (right, an, wan, man, wati) confix (to-ness, role, right, right, etc.

A. Leaving $=$ morpheme bound men-kan, page 01

B. Make $=$ morpheme bound mem, page 01

C. Dreaming $=$ morpheme bound ber, page 01

D. Take $=$ morpheme meng, page 02

E. Search $=$ morpheme men, page 02

F. Miracle $=$ morpheme ke-an page 02

G. Beauty $=$ morpheme ke-an page 02,73

H. Storytelling=morpheme ber, page 02

I. Starting=morpheme ber, page 02

J. Saving=morpheme men, page 02

K. Confidence $=$ morpheme ke-an, page 02

L. Ease $=$ morpheme an, page 02

M. Eating=morpheme me, page 03

$\mathrm{N}$. United $=$ morpheme ber, page 03

O. Funeral $=$ morpheme pe-an, page 03

P. Upcoming $=$ morpheme men, page 03

2. Morpheme is called proclitic, showing the meaning of doing an action or deed, the basic form of enclklitik indicates the meaning of belonging [15].

The clit in the novel is 509 words, my clit is 19 words, while my proclitic is 3 words, so the total number in the novel is 531 words. The data below includes bound morphemes in the form of clitics and proclitics.

A. The name $=$ morpheme bound $n y a$, page 02

B. His dream $=$ his morpheme nya, page 02

C. His heart=his morpheme $n y a$, page 02

D. His life $=$ his morpheme $n y a$, page 04

E. The song=the morpheme nya, page 05

F. The film=the morpheme nya, page 06

$\mathrm{G}$. His body $=$ his morpheme nya, page 06

H. His skin=his morpheme $n y a$, page 06

I. Default $=$ morpheme $n y a$, page 07

J. Friends $=$ morpheme $n y a$, page 08

$\mathrm{K}$. His girlfriend=his morpheme $n y a$, page 09

L. The title=the morpheme $n y a$, page 09

M. The girl=her morpheme $n y a$, page 09

$\mathrm{N}$. His neighbor=his morpheme $n y a$, page 10

O. His gang=his morpheme nya, page 11

P. His sister=her morpheme $n y a$, page 11

Q. The computer=the morpheme nya, page 11

$\mathrm{R}$. His body $=$ his morpheme nya, page 12

S. Its head=its morpheme nya, page 12,59

$\mathrm{T}$. The costume $=$ the morpheme nya, page 13

U. Glasses $=$ morpheme nya, page 13

$\mathrm{V}$. His mind=his morpheme nya, page 13

$\mathrm{W}$. Ears $=$ the morpheme nya, page 16
3. Particle words are a kind of task word that has a special form, which is very concise or small with certain functions.

Particles are contained in the novel 8 words, particles are 2 words, while particles are 1 word, so the total number of word particles in the novel is 11 words. The data below includes bound morphemes in the form of particles.

A. Is not $\mathrm{it}=$ morpheme bound $\mathrm{kah}$, page 01

B. Is it possible=that morpheme bound $\mathrm{kah}$, page 01

C. Comes $=$ morpheme lah, page 08

D. Comes $=$ morpheme lah, page 08

E. Not=morpheme lah, page 38,53

F. Naturally $=$ morpheme $l a h$, page 167

G. Whatever $=$ morpheme lah, page 260

H. Fate $=$ morpheme lah, page 260

I. Arise $=$ morpheme lah, page 274

J. Continue $=$ morpheme lah, page 349

K. Office $=$ morpheme lah, page 353

From the data above, the use of morpheme is divided into three parts, namely affixation which consists of 474 words, clitika and proclication 531 words, while particles consist of 11 words. So the total number of bound morphemes is 1,016 words.

The results of the study resulted from the selection of bound morphemes in the $5 \mathrm{~cm}$ novel by Donny Dhirgantoro, this study was carried out in stages because bound morphemes were analyzed per word, basically bound morphemes were found prefixes totaling 474 words, clits of 528 words while parets of 11 words, so morphemes were dominant in the novel is klitika.

Based on the objectives to be achieved, namely the description of the use of bound morphemes used by Donny Dhirgantoro, it can be stated that there are variations in morphemes used. The total number of morphemes bound is 1,016 words.

Bound morphemes are morphemes that cannot stand alone and have no meaning. The meaning of morpheme is bound only after the morpheme is associated with other morphemes [16]. All prefixes (prefixes, inserts, suffixes, and combinations of prefixes and suffixes) are classified as bound morphemes. In addition, small elements such as the particle-i, -lah, -kah, and other forms that cannot stand alone are also classified as bound morphemes. Morphemes are bound by affixes consisting of prefixes, infixes, suffixes and confixes, namely:

1. Prefix prefixes -ber, -ter, -meng, -per, -di.

The united word combination of bound morpheme and free morpheme, bound morpheme and free morpheme one, is said to be morpheme-bound because it cannot be used in a speech or writing, while it sounds like it is said to be free already has meaning or meaning and can be used in a narrative.

The word sounds a combination of free morpheme and bound morpheme, bound morpheme and free hear morpheme, bound-morpheme cannot stand alone in a narrative.

The word interferes with the combination of free morpheme and bound morpheme, morpheme - bound and morpheme free, bound morpheme - can not be used in a narrative.

The word sent is a combination of free morpheme and bound morpheme, morpheme -in bound and morpheme free, bound morpheme -in cannot be used in a narrative.

2. Infix (insert-el, -em, -er, -and -el) is not found in the $5 \mathrm{~cm}$ novel by Donny Dhirgantoro. 
3. Suffix (suffix, -kan, -an, -wan, -man and -wati)

The word give a combination of free morpheme and bound morpheme, bound morpheme and free morpheme, bound morpheme cannot be used in a narrative.

The word courtship combination of free and bound morphemes, bound-morphemes and free-girlfriend morphemes, bound-morphemes cannot be used in a narrative because it does not contain meaning or meaning.

4. Conflicts (prefixes, endings, ke-an, per-an, di-kan, meng-kan, pe-an, me-kan, men-kan, mem-kan).

The word intelligence combination of free morpheme and bound morpheme, morpheme to morpheme bound to smart morpheme free morpheme, morpheme bound to it cannot be used in a narrative because it does not contain meaning or meaning.

The word combination corresponds to free morpheme and bound morpheme, morpheme per morpheme bound to free morpheme letter, morpheme bound role cannot be used in a narrative because it does not contain meaning or meaning [17].

The word needed a combination of free morpheme and bound morpheme, morpheme bound morpheme requires free morpheme, bound morpheme cannot be used in a narrative because it does not contain meaning or meaning.

The word gets rid of free morpheme and bound morpheme, morpheme bound bound morpheme free morpheme, bound morpheme cannot be used in a narrative because it does not contain meaning or meaning.

The word mountain of free morpheme and bound morpheme, morpheme of bound morpheme free mountain morpheme, morpheme bound of role cannot be used in a narrative because it does not contain meaning or meaning.

The word derives from free morpheme and bound morpheme, morpheme is bound morpheme down free morpheme, bound morpheme cannot be used in a narrative because it does not contain meaning or meaning.

The word dropped a combination of free morpheme and bound morpheme, morpheme bound free morpheme free morpheme, bound morpheme cannot be used in a narrative because it does not contain meaning or meaning.

The word cleans the combination of free morpheme and bound morpheme, morpheme is bound to free morpheme, free morpheme, bound morpheme cannot be used in a narrative because it does not contain meaning or meaning.

Seen from the use of particles lower than prefixes, especially the use of morphemes -in 4, men, 24, -me 32, -meng 33 , -mem 42 , -ter 47 , -ber 114, while the number of particles is only 11 words. So the highest use of clitika found in the novel.

1. Words that have prefixes are:
A. Morpheme makes, prefix -mem
B. Morpheme dreams, prefix -ber
C. Morpheme takes, prefixes meng
D. Morpheme runs, prefixes ber
E. Morpheme sounds, prefix ter
F. Morpheme takes, prefixes meng
G. Morpheme admires, prefixes meng
H. Morpheme starts, prefixes ber
I. Morpheme hates, prefixes mem
J. Crested morphemes, prefixes ber

$\mathrm{K}$. Morpheme is used, prefix ter

L. Morpheme is made, prefixes $d i$

M. Morpheme laughs, prefixes ter

N. Morpheme says, prefixes ber

O. Morpheme breathing, prefixes ber

2. Words that have a suffix, namely:
A. Street morphs, suffixes an
B. Morpheme of mind, suffixes an
C. Morpheme is dating, suffixes an
D. Morphem is proud, suffixes kan
E. Morpheme writing, suffixes an
F. Sleeping morpheme, suffixes an
G. Morphem surrender, suffixes kan
H. Morphem give, suffixes kan
I. Morphem left, the confix men-kan
J. Morphem give, suffixes kan
K. Morpheme of beauty, confixity ke-an

3. Words that have a confection ke-an, namely:
A. Morpheme of beauty, confix ke-an
B. Morpheme of miracles, confix ke-an
C. Morpheme believe, confix ke-an
D. Morpheme runs out, confix ke-an
E. Morpheme mostly, confix ke-an
F. Yellowish morpheme, confix ke-an
G. Morpheme satiety, confix ke-an
H. Morpheme pride, confix ke-an
I. Morpheme mostly, confix ke-an
J. Morphem ugliness, confix ke-an
$\mathrm{K}$. Morpheme loses, confixes ke-an
L. Morpheme gets caught, confix ke-an
M. Morpheme tenderness, confix ke-an
N. Morpheme confusion, confix ke-an
O. Morpheme stands for, confix ke-an
P. Morpheme of events, confix ke-an
Q. Morpheme madness, confix ke-an
R. Morpheme loses, confix ke-an
S. Morpheme is flooded, confix ke-an
T. Morpheme gets caught, confix ke-an
U. Morpheme warmth, confix ke-an
V. Frequent morphemes, confix ke-an
W. Morpheme longing, confix ke-an
$\mathrm{X}$. Morpheme of interest, confix ke-an
Y. Morpheme of courage, confix ke-an
Z. Morpheme of beliefs, confix ke-an

4. Words that conflict per-an
A. Morpheme is a battle, a confict per-an
B. Morpheme travel, confix per-an
C. Morpheme correspondence, confix per-an
D. Morpheme travel, confix per-an
E. Morpheme of friendship, confictions per-an

5. The word confix di-kan, includes: Morpheme is needed, confix di-kan. The confusing meng-kan word is:

A. Morpheme collects, conficts meng-kan

B. Morphem says, confix meng-kan

C. Morphem produces, confix meng-kan

D. Morpheme eliminates, confix meng-kan

6. Words that confix pe-an are: 

A. Mountain morpheme, confix pe-an
B. Morpheme warning, confix pe-an
C. Morpheme of trees, order confix pe-an
D. Morpheme of rural, confix pe-an

7. 7Confirmed words are me-kan
A. Morpheme plays, confix me-kan
B. Morpheme raises, confix me-kan
C. Morpheme raises, confix me-kan
D. Morpheme launches, morpheme me-kan
E. Morpheme let go, confix me-kan

8. The confusing word men-kan is:
A. Morpheme is passionate, comfix men-kan
B. Morpheme hurts, confix men-kan
C. Morpheme sends, confix men-kan

9. Clitika and proclitika include: $n y a$, dan $k u$.

A. Morpheme his body, clit nya

B. The skin morpheme, clit nya

C. Morpheme his sister, clit nya

D. Morpheme his room, clit nya

E. Morpheme is the train, clit nya

F. Morpheme my year, clit $k u$

G. My morpheme, clit $k u$

H. Morpheme I try, proklitika $k u$

10.Particles that include lah, kah and pun.

A. Morpheme is not it, particles kah

B. Morpheme is possible, particles kah

C. Morpheme appears, the particle lah

D. Morpheme is not it, particles kah

E. Morphemes are natural, particles lah

F. Morpheme whatever, particles lah

G. Morpheme Fate, even particles pun

H. Morpheme arises, it's the particles lah

I. Keep morphing, particles lah

J. Office morpheme, particles lah

\section{Conclusion}

From the results of data analysis and findings about the use of morpheme forms bound to a novel entitled $5 \mathrm{~cm}$ by Donny Dhirgantoro, the following conclusions can be drawn:

In the use of bound morphemes in the novel there are 3 types of ways to determine a bound morpheme, namely: Affixation is the process of affixing an basic form. In this process the elements involved (1) the basic form, (2) affixes, and (3) the resulting grammatical meaning. Affix is a form, usually in the form of bound morphemes, which is added to a basis in the process of word formation. Morpheme called proclitik shows the meaning of doing an action or deed. For example the klitika of his house is morpheme, the campus is his morpheme, my mother is my morpheme, his jacket is his morpheme. While particles are a kind of task word that has a special form.

The word sounds a combination of two morphemes consisting of bound morphemes and free morphemes, walking words a combination of two morphemes consisting of bound morphemes and free morphemes. The word food consists of two morphemes, eating and -an, the word give consists of two morphemes, morpheme berries and morphemes. Most words consist of two morphemes, many morphemes and late morphemes.

From the discussion of the data above, it can be found that affixation consists of 474 words, clits 531 words while particles consist of 11 words. So the total amount contained in the novel is 1,016 words.

\section{References}

[1] W. Sandler and D. Lillo-Martin, Sign language and linguistic universals. Cambridge University Press, 2006.

[2] D. L. Bolinger, "Rime, assonance, and morpheme analysis," Word, vol. 6, no. 2, pp. 117-136, 1950.

[3] E. König, The meaning of focus particles: A comparative perspective. Routledge, 2002.

[4] M. Ramlan, "Bahasa Indonesia, Morfologi Suatu Tinjauan Deskriptif.” Yogyakarta: CV Cukaryono, 1983.

[5] S. AR-RUM, "PROSES MORFOLOGI PADA TERJEMAHAN AL QURAN."

[6] M. Ramlan, Morfologi: Suatu tinjauan deskriptif. Karyono, 1983.

[7] S. Poedjosoedarmo, Morfologi bahasa jawa, vol. 19. Pusat Pembinaan dan Pengembangan Bahasa, Departemen Pendidikan dan Kebudayaan, 1979.

[8] I. Istiqomah, "Morfem Bebas dan Morfem Terikat Kata Kerja Bahasa Arab," SKRIPSI Jur. Sastra Arab. Sastra UM, 2009.

[9] D. L. Bolinger, "On defining the morpheme," Word, vol. 4, no. 1, pp. 18-23, 1948.

[10] G. Booij, The grammar of words: An introduction to linguistic morphology. Oxford University Press, 2012.

[11] T. R. KBBI, "Kamus besar bahasa indonesia (Edisi Keempat)," Jakarta Pus. Bhs. Dep. Pendidik. Nas., 2005.

[12] R. D. Pradopo, "Metodologi Penelitian Sastra," Yogyakarta PT. Hanindita Graha Widia, 2001.

[13] L. J. Moleong, "Metodologi Penelitian Kualitatif, 2005," Bandung Remaja Rosdakarya. Ndara, Taliziduhu. Pembang. Masyarakat, Mempersiapkan Masy. Tinggal Landas, 1990.

[14] S. Samsinar, "Pengaruh Pemberian Tuak terhadap Morfologi Fetus Mencit (Mus musculus) ICR.” Universitas Islam Negeri Alauddin Makassar, 2018.

[15] S. Suyatno, "PROSES MORFOLOGIS MORFEM DASAR TERIKAT BAHASA INDONESIA.” Fakultas Ilmu Budaya, 2009.

[16] M. Taft and X. Zhu, "The representation of bound morphemes in the lexicon: A Chinese study," Morphol. Asp. Lang. Process., pp. 293-316, 1995.

[17] K. Kurisu, The phonology of morpheme realization, vol. 1. University of California, Santa Cruz, 2001. 